\title{
Quantitative assessment of the scope of content of selected topographic maps of Polish lands from the 19th and the first half of the 20th century*
}

\begin{abstract}
The author presents an overview of the scope of content of selected topographic maps of Polish lands from the 19th and the first half of the 20th century in its quantitative aspect. 19 maps were analysed and a common conceptual model linked to the Database of Topographic Objects (DBTO10k) was developed on the basis of catalogues of object types. Quantitative statistics were also prepared for the object types from maps before and after harmonization. Differences between their numbers within the same maps reflect the conceptual variety of said maps. The number of types of objects (before and after harmonization) was then juxtaposed with selected thematic layers: water network, transport network, land cover, buildings, structures, and equipment, land use complexes, localities and other objects. Such factors as scales, publication dates and topographic services which created analysed maps were also taken into consideration. Additionally, the analysed maps demonstrate uneven levels of generalization. Inclusion of objects typical for large-scale cartography on topographic and general maps is one of the distinctive features.
\end{abstract}

Keywords: old topographic maps, maps' scope of content, topographic objects, databases, Database of Topographic Objects (DBTO10k)

\section{Introduction}

Research focusing on old maps has very long and rich tradition. Studies resulting from the work of former cartographers have been analysed in various contexts, the most important of which are: circumstances in which maps were created, their accuracy, scope and ways of depicting geographical content, but also their reception and further fate. The subject of all the above-listed studies was the same, but the objectives differed. Some researchers focused on maps as documents reflecting the contemporary world and the possibilities of its spatial representation (S. Pietkiewicz 1960, M. Stankiewicz 2000, A. Konias 2010, and F.P. Faluszczak 2011). On the other hand, other researchers

\footnotetext{
* The research presented in this article constitutes part of the author's doctoral thesis titled "The concept of historical topographic objects' database". The manuscript is available in the library of the Faculty of Geography and Regional Studies of the University of Warsaw.
}

assessed the maps foremost in terms of their usefulness for further research, mostly in historical geography where old maps still remain one of the main sources of information (W. Iwańczak 2008, B. Konopska et al. 2012, and A. Czerny 2015).

The review of the scope of content of selected topographic maps of Polish lands from the 19th and the first half of the 20th century represents the second of the aforementioned trends, which is only reinforced by the fact that such studies very often include analyses which underlie geographic and historical research. Any analysis of geohistorical landscape of Polish territories involves dealing with many series of maps which were developed by topographic services of the partitioning states, which means that they were prepared on the basis of different instructions, keys to symbols, and methods of content presentation, using different degrees of content generalization and different underlying mathematical foundations. Consequently, any collection of such maps needs to be harmonized and 
integrated, not only in terms of geometry (georeferencing), but also in terms of the maps' conceptual aspects, before it can be used effectively for any analysis (J. Kuna 2014, J. Plit 2014, T. Panecki 2014, 2015).

The main focus of the article is quantitative assessment of the content of 19 old topographical maps of Polish lands developed by topographic services of three various countries, in different years and at different scales. The research consisted in comparing the number of object types included in the maps' keys to symbols, using the object types to develop a common conceptual model, and assessing the scope of content within such model. The common model was based on the contemporary Database of Topographic Objects (DBTO10k). It is a reference database for topographic and thematic maps. Its content has been organised in accordance with three levels of specificity feature class category (9), feature class (57) and object types (286), and the main criterion used to define the content is physiognomy (Rozporządzenie... 2011; R. Olszewski, D. Gotlib 2013).

The model developed for this article allows for comparing the scope of content of old maps at the unified level of generalization, because the object types defined in the keys to symbols have been assigned to the corresponding types of objects from the modern database. Although the maps selected for the analysis largely differ from the DBTO10k standard in terms of their scales, it was not possible to use the Database of General Geographic Objects (DBGGO) in the research, although it was more similar to them in this respect. The DBGGO contains no data concerning buildings and - to a large extent - land use complexes which constituted elements of the content of $1: 300,000$ maps.

\section{Source materials}

The analysis was conducted on the basis of maps from 1800-1939. The beginning of the period corresponds to the breakthrough in topographical cartography and its end is marked with the outbreak of World War II and the end of the work of the interwar Polish Military Geographical Institute (MGI). The set of the analysed maps includes German maps from the World War II period which were direct continuation of works which had been carried out since the end of the 19th century.

The most significant part of the selection process was to make sure that the maps chosen for the analysis are representative. They should be diverse in terms of their scales, elaboration dates and topographic services of countries in which they were created (table 1).

Tab. 1. Criteria used for maps selection

\begin{tabular}{|c|c|}
\hline \multirow{2}{*}{ Scales } & $1: 25,000-1: 28,800$ \\
& $1: 75,000-1: 150,000$ \\
$1: 200,000-1: 300,000$ \\
\hline Date of issue & $1800-1870,1870-1939$ \\
\hline \multirow{2}{*}{ Topographic service } & $\begin{array}{c}\text { Polish, German, Austrian, } \\
\text { Russian }\end{array}$ \\
\hline
\end{tabular}

Firstly, it is possible to identify a succession of scales of the maps from this period and differentiate between them on the basis of this aspect. Secondly, the analysed period can be divided into two shorter periods, and the maps can be divided into two subgroups, in accordance with their elaboration dates - a group of maps created before 1870 and a group for maps created after that date (which constitutes a symbolic caesura for the modern topographic cartography). Thirdly, four topographic services could be distinguished among the maps' creators.

Ultimately, a matrix was elaborated for twenty-four maps which fulfilled the above-mentioned assumptions (table 2). It was impossible to fill it completely, and the shortcomings result from the unavailability of a sufficient number of map sheets (Russian maps), keys to symbols (Austrian and Russian maps), or simply from the lack of maps that meet the above-listed criteria (Russian and Polish maps).

The selected set of maps included also maps created as a result of plate table surveys: Austrian Second Military Survey, German Urmesstischblätter (UMTB), Messtischblätter (MTB), as well as a detailed MGI map. At the point of their elaboration, they were most detailed topographic maps available and they were used as the basis for elaboration of smaller-scale maps, such as 1:75,000-1:150,000 maps: the Austrian Spezialkarte der Osterreichisch-Ungarischen Monarchie, which is exceptionally rich in content, the German Karte des Deutchen 
Tab. 2. Matrix of maps fulfilling given criteria. Maps' short names which are used further are given in square brackets

\begin{tabular}{|c|c|c|c|c|c|}
\hline & & Austria & Germany & Russia & Poland \\
\hline \multirow{2}{*}{$\begin{array}{c}1: 21,000 \\
-1: 28,800\end{array}$} & $\begin{array}{l}\text { before } \\
1870\end{array}$ & $\begin{array}{l}\text { Second Military } \\
\text { Survey }\end{array}$ & $\begin{array}{l}\text { Urmesstischblätter } \\
\text { [UMTB] }\end{array}$ & $x$ & $x$ \\
\hline & $\begin{array}{l}\text { after } \\
1870\end{array}$ & $x$ & $\begin{array}{l}\text { Messtischblätter } \\
\text { [MTB] }\end{array}$ & $x$ & $\begin{array}{l}\text { MGI detailed } \\
\text { map }\end{array}$ \\
\hline \multirow[b]{2}{*}{$\begin{array}{c}1: 75,000 \\
-1: 150,000\end{array}$} & $\begin{array}{l}\text { before } \\
1870\end{array}$ & Kummersberg map & Gilly map & $\begin{array}{l}\text { Three-verst } \\
\text { map }\end{array}$ & $\begin{array}{l}\text { Quatermaster's } \\
\text { map }\end{array}$ \\
\hline & $\begin{array}{l}\text { after } \\
1870\end{array}$ & $\begin{array}{l}\text { Spezialkarte der } \\
\text { Österreichisch- } \\
\text {-Ungarischen } \\
\text { Monarchie }\end{array}$ & $\begin{array}{l}\text { Karte des Deutches } \\
\text { Reiches [KdDR]; } \\
\text { Karte des westlichen } \\
\text { Russlands [KdWR] }\end{array}$ & $\begin{array}{l}\text { Two-verst } \\
\text { map }\end{array}$ & $\begin{array}{l}\text { MGI tactical } \\
\text { map }\end{array}$ \\
\hline \multirow{2}{*}{$\begin{array}{c}1: 200,000 \\
-1: 300,000\end{array}$} & $\begin{array}{l}\text { before } \\
1870\end{array}$ & Liesganig map & Reymann map & $x$ & $\begin{array}{l}\text { Chrzanowski } \\
\text { map }\end{array}$ \\
\hline & $\begin{array}{l}\text { after } \\
1870\end{array}$ & $\begin{array}{l}\text { Generalkarte } \\
\text { von Mitteleuropa } \\
{[\text { GKME] }}\end{array}$ & $\begin{array}{l}\text { Übersichtskarte } \\
\text { von Mitteleuropa } \\
\text { [UKvME] }\end{array}$ & $x$ & $\begin{array}{l}\text { MGI operational } \\
\text { map }\end{array}$ \\
\hline
\end{tabular}

Tab. 3. List of maps

\begin{tabular}{|c|c|c|}
\hline ID & Map name, scale, date of issue & $\begin{array}{l}\text { Source of information for topographic } \\
\text { feature types }\end{array}$ \\
\hline \multicolumn{3}{|c|}{ Austrian maps } \\
\hline 1 & Second Military Survey, 1:28,800, 1807-1869 & specimen sheet (1834) \\
\hline 2 & Spezialkarte..., 1:75,000, 1875-1915 & specimen sheet (1904) \\
\hline 3 & Kummersberg map, 1:115,200, 1855 & map sheet $(06,1855)$ \\
\hline 4 & GKME, 1:200,000, 1872-1918 & list of symbols (J. Libiński 1912) \\
\hline 5 & Liesganig map, 1:288,000, 1824 & map sheet (Tab. XIX, 1824) \\
\hline \multicolumn{3}{|c|}{ German maps } \\
\hline 6 & UMTB, $1: 25,000,1820-1876$ & specimen sheet (1818) \\
\hline 7 & MTB, 1:25,000, 1875-1945 & map sheet $(3661,1940)$ \\
\hline 8 & KdDR, 1:100,000, 1875-1945 & specimen sheet (1887) and map sheet $(67,1944)$ \\
\hline 9 & KdWR, 1:100,000, 1914-1921 & specimen sheet (1911) \\
\hline 10 & Gilly map, 1:150,000, 1802-1803 & map sheet $(C 1,1803)$ \\
\hline 11 & Reymann map, 1:200,000, 1806-1908 & specimen sheet (1838) \\
\hline 12 & UKvME, 1:300,000, 1893-1945 & map sheet (R52, 1913 and R50, 1943) \\
\hline \multicolumn{3}{|c|}{ Russian maps } \\
\hline 13 & Two-verst map, 1:84,000, 1883-1935 & list of symbols (J. Lewakowski 1920) \\
\hline 14 & Three-verst map, 1:126,000, 1846-1918 & list of symbols (J. Lewakowski 1920) \\
\hline \multicolumn{3}{|c|}{ Polish maps } \\
\hline 15 & Quatermaster's map, 1:126,000, 1839-1843 & map sheet (Kol. II, Sek. VIII, 1839) \\
\hline 16 & Chrzanowski map, 1:300,000, 1859 & map sheet $(05,1859)$ \\
\hline 17 & MGI detailed map, 1:25,000, 1919-1939 & list of symbols (WIG, 1937) \\
\hline 18 & MGI tactical map, 1:100,000, 1919-1939 & list of symbols (WIG, 1937) \\
\hline 19 & MGI operational map, 1:300,000, 1919-1939 & list of symbols (WIG, 1937) \\
\hline
\end{tabular}


Reiches (KdDR) map, Russian verst maps, and the MGI tactical map. An especially unique map of this kind is the German 1:100 000 map of Western Russia (Karte des westlichen Russlands - KdWR) which was created using only the Russian map of similar scale as its basis. Some of the older maps of this type include Gilly map of Prussia, the Austrian Kummersberg map and the Topographic Map of the Polish Kingdom developed by Polish topographers - all of them were developed as a result of generalization of precise (for the time) topographic surveys. The analysis covers also topographic-and-general-scale maps, such as Reymann 1:200,000 map which showcases a very rich catalogue of objects (especially economic facilities), an Austrian map of the same scale and German and Polish 1:300,000 maps (table 3 ).

Map selection was not the only significant factor influencing the study - indication of a reliable list of object types presented on the maps was equally important. Three types of keys to symbols were used: specimen sheets (mainly for German maps), lists of symbols from the inter-war period (Russian maps, Generalkarte von Mitteleuropa - GKME, and MGI maps), and map legends on the map sheets (German maps). Two versions of the keys to symbols an older and a newer version - were used for two maps: KdDR and Übersichtskarte von Mitteleuropa (UKvME).

\section{Methodology}

In the opinion of the author of this article, the variety of the scope of maps' content can be only analysed on the basis of a uniform conceptual model. In such a model, the object types identified on the old maps are assigned to common conceptual categories, which allows for their classification. The common conceptual categories used in this analysis were the DBTO10k object types to which the object types presented on the maps were assigned. The object types from the old maps were identified foremost with those types from the DBTO10k model which corresponded to them conceptually, which allowed for development of a coherent classification of topographic objects shown on old maps.

The starting point of harmonization of the content of the maps was development of the database containing lists of object types specified in the keys to symbols (fig. 1). A symbol representing a given terrain object was usually chosen as the object type. However, there were also some exceptions - in some cases one symbol in a map legend corresponded to two objects (e.g. a symbol indicating "wood with
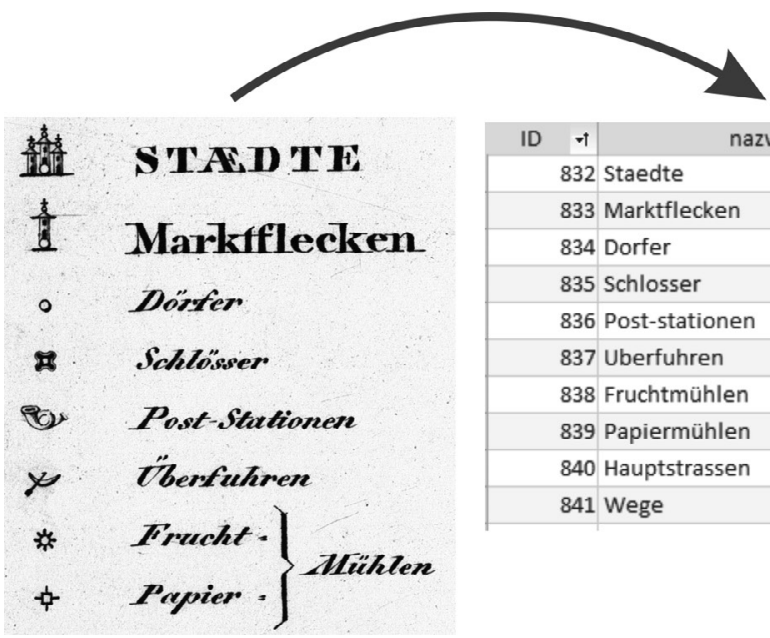

\begin{tabular}{|l|l|l|}
\hline \multicolumn{1}{|c|}{ nazwa_h } & \multicolumn{1}{|c|}{ nazwaPolska_h } \\
\hline 832 Staedte & Miasta \\
\hline 833 Marktflecken & Miasta targowe \\
\hline 834 Dorfer & Wsie \\
\hline 835 Schlosser & Zamki \\
\hline 836 & Post-stationen & Stacje pocztowe \\
\hline 837 Uberfuhren & Przeprawa przez rzekę \\
\hline 838 & Fruchtmühlen & Młyny zbożowe \\
\hline 839 & Papiermühlen & Papiernie \\
\hline 840 & Hauptstrassen & Drogi główne \\
\hline 841 Wege & Drogi \\
\hline
\end{tabular}

Fig. 1. Key to symbols of the Liesganig map $(1: 288,000,1824)$. While transforming map legend to the database format, names of topographic feature types were considered both in original notation (i.e. German) and Polish 
clearings" constitutes in fact two different topographic objects) and in others, one object type could be represented twice (e.g. as a symbol of a farmstead and as an explanatory abbreviation in the list of symbols). Symbols which did not constitute topographic objects, e.g. markings indicating the direction of the river or road exits, were also included in the map legends. Different types of topographic objects understood as graphic representations of terrain objects were taken into account when converting keys to symbols into the database (M. Stankiewicz 2005). 2766 object types were recorded in the database on the basis of the analysis of 19 topographic maps.

Three methods of integration of object types from the old maps and DBTO10k were used to develop a common data model:

1. Semantic assignment consisted in searching for equivalents of the types of objects identified on the old maps among the object types distinguished by the DBTO10k. The assigned objects are similar to each other, e.g. in terms of their physiognomy or function, but this does not mean that they are semantically conform.

2. Extending the scope of the content of DBTO10k took place when no significant equivalents of object types from the old maps could be found in the modern database. These were such objects as, for example: gallows, signposts, border stones or wrecks [of ships]. In such cases, the informative scope of the contemporary database was expanded. As DBTO10k has a three-level structure, all object types had to be not only identified within the database as object types (third level of the structure), but also assigned to an appropriate class and class category of objects (respectively: second and third level of classification).

3. The metalegend has a form of a universal classification of object types constituting conceptual generalisation of objects identified on the analysed maps (I. Gołębiowska et al. 2012, T. Panecki 2014). Individual object types are assigned to more general conceptual categories, identified on the basis of a criterion which is as uniform as possible. In this case, the objects were not identified with their equivalents from DBTO10k, but more general types were developed on the basis of both these groups. This approach was used for the road network and localities.
It was then used as a basis for development of a data model for historical topographic objects, based on the DBTO10k structure. Just like the contemporary database, it assumes a three-level hierarchy and a division into: object class categories (9), object classes (43 out of 57 in DBTO10k) and object types (137 out of 286 in DBTO10k). Of these, 26 object types are distinguished only on the old maps and not included in the modern database. They are primarily landmarks and natural objects whose depiction on the maps used to be necessary, whereas nowadays they do not fulfil any significant role in cartography (e.g. gallows, hedges or road signs).

Two types of data were analysed for a quantitative comparison of the content of the maps:

- the number of object types before the harmonization corresponding to the number of object types identified in the maps' keys to symbols,

- the number of object types after harmonization obtained as a result of integration of the content of the old maps into a common data model based on DBTO10k.

The quantitative difference between the number of object types before and after harmonization is important in the analysis. It can be interpreted as differentiation of objects in terms of additional characteristics (attributes). For example, there were 22 types of bridges indicated on the Austrian Spezialkarte which were varied in terms of the material used in the bridges' structures, their supports and forms of transportation they were meant to serve. All these 22 object types were classified as one object ("bridge"), with relevant attributes, in a harmonized model.

It can be therefore said that the difference (the decrease of the number of object types after harmonization) reflects the degree of conceptual differentiation of maps, as the "bridge" (as the "primary object") and its attributes are distinguished separately. Considering bridges for one more example - all of their various types (object types in the key to symbols) were the basis of arriving at the "number of object types before the harmonization", while the single object type "bridge" (and similar ones, on the basis of conceptual harmonization from DBTO10k) was the basis for the "number of object types after harmonization". 


\section{The scope of content of the maps in their quantitative aspect}

Further parts of the article focus on the content of the maps analysed in relation to their general quantitative aspects, which takes into consideration also their division into individual object class categories (thematic layers) and the three criteria used for the selection of representative maps: scale and publication date, as well as the topographic service of the state responsible for creation of each map.

\subsection{General approach}

The above-mentioned values (numbers of object types before and after harmonization) were compared for each analysed map and the percentage decrease was calculated in each case (table 4). On average, the decrease for the entire set of maps amounted to $62.7 \%$. It means that slightly less than a half of the scope of content of old maps consists of so-called basic objects, that is, object types harmonized to a common data model. The remaining part of the scope of their content consist of attributes (in the meaning of contemporary criteria of modelling topographic objects). It can be also stated that the lower the decrease of the number of object types after harmonization, the less detailed the map (in the sense of the differentiation of the same objects in relation to certain characteristics) or the higher the number of homogeneous and internally non-diverse object types in its scope of content.

Tab. 4. Relation between topographic feature types before and after data harmonization. Maps were arranged according to the percentage decrease of feature types after harmonization. Colors correspond to the topographic services developing the maps (green - Austrian, blue - German, red - Russian, orange - Polish)

\begin{tabular}{|r|c|c|c|l|}
\hline ID & $\begin{array}{c}\text { Number } \\
\text { of feature } \\
\text { types before } \\
\text { harmonization }\end{array}$ & $\begin{array}{c}\text { Number } \\
\text { of feature } \\
\text { types after } \\
\text { harmonization }\end{array}$ & $\begin{array}{c}\text { Percentage } \\
\text { decrease } \\
\text { of feature } \\
\text { types after } \\
\text { harmonization }\end{array}$ & \multicolumn{1}{|c|}{ Map name } \\
\hline 1 & 39 & 27 & 30.8 & UKvME, 1:300,000, 1893-1945 (sheet R52, 1913) \\
\hline 2 & 29 & 17 & 41.4 & Chrzanowski map, 1:300,000, 1859 \\
\hline 3 & 119 & 68 & 42.9 & KdDR, 1:100,000, 1875-1945 (sheet 67, 1944) \\
\hline 4 & 67 & 36 & 46.3 & Kummersberg map 1:115,200, 1855 \\
\hline 5 & 151 & 76 & 49.7 & MTB, 1:25,000, 1875-1945 \\
\hline 6 & 52 & 26 & 50.0 & Gilly map, 1:150,000, 1802-1803 \\
\hline 7 & 37 & 18 & 51.4 & Liesganig map, 1:288,000, 1824 \\
\hline 8 & 113 & 54 & 52.2 & UKvME, 1:300,000, 1893-1945 (sheet R50,1943) \\
\hline 9 & 38 & 18 & 52.6 & GKME, 1:200,000, 1872-1918 \\
\hline 10 & 131 & 62 & 52.7 & KdDR, 1:100,000, 1875-1945 (reference sheet 1887) \\
\hline 11 & 265 & 116 & 56.2 & MGI detailed map, 1:25,000, 1919-1939 \\
\hline 12 & 242 & 105 & 56.6 & MGI tactic map, 1:100,000, 1919-1939 \\
\hline 13 & 117 & 50 & 57.3 & Two-verst map, 1:84,000, 1883-1935 \\
\hline 14 & 80 & 34 & 57.5 & Quatermaster's map, 1:126,000, 1839-1843 \\
\hline 15 & 168 & 69 & 58.9 & MGI operational map, 1:300,000, 1919-1939 \\
\hline 16 & 124 & 49 & 60.5 & Reymann map, 1:200,000, 1806-1908 \\
\hline 17 & 130 & 50 & 61.5 & UMTB, 1:25,000, 1820-1876 \\
\hline 18 & 180 & 68 & 62.2 & KdWR, 1:100,000, 1914-1921 \\
\hline 19 & 147 & 52 & 64.6 & Three-verst map, 1:126,000, 1846-1918 \\
\hline 20 & 200 & 70 & 65.0 & Second Military Survey, 1:28,800, 1807-1869 \\
\hline 21 & 255 & 84 & 67.1 & Spezialkarte..., 1:75,000, 1875-1915 \\
\hline & & & &
\end{tabular}


The first on the list is a German 1:300,000 map whose content has been reduced to the smallest extent $(30.8 \%)$ after its harmonization to the database form. This means that the map depicted mostly general object types which were at the same time largely consistent with the common data model, and that about $1 / 3$ of the map's scope of content constitutes additional characteristics of the objects. The Austrian maps (scales 1:28,800 and 1:75,000) have the most diverse content - the number of depicted object types decreased for them by about $65 \%$. It is a result of great diversity of buildings (mainly sacral buildings), infrastructures (bridges) and economic facilities (production plants).

\subsection{Thematic layers}

The quantitative analysis of the scope of content of old maps was also carried out within selected object class categories from DBTO10k: water network, transport network, land cover, structures, buildings and equipment, land use complexes, localities and other objects. The analysis does not include utility infrastructure and protected areas, as such elements of the layers were indicated only on a few maps.

An overview of the number of types of objects of water network, including rivers, canals and drainage ditches, shows that the highest numbers of such object types were indicated on the Austrian maps at the scales of $1: 28,800$ and $1: 75,000$, and that they were also showcased there in the most diverse way. There was a $75 \%$ and $73.5 \%$ drop, respectively, in the number of object types for these two maps, whereas the average for all maps was $37.7 \%$ (fig. 2). The Austrian 1:28,800 map has separate symbols for rivers flowing through clay, intermittent rivers and muddy rivers, all of which were classified as "rivers" in the final model. Some of the maps differentiate between rivers and channels, navigable and non-navigable ones, which influences the conceptual diversity. Drainage ditches are also an element of this layer, and they can be divided into dry and wet

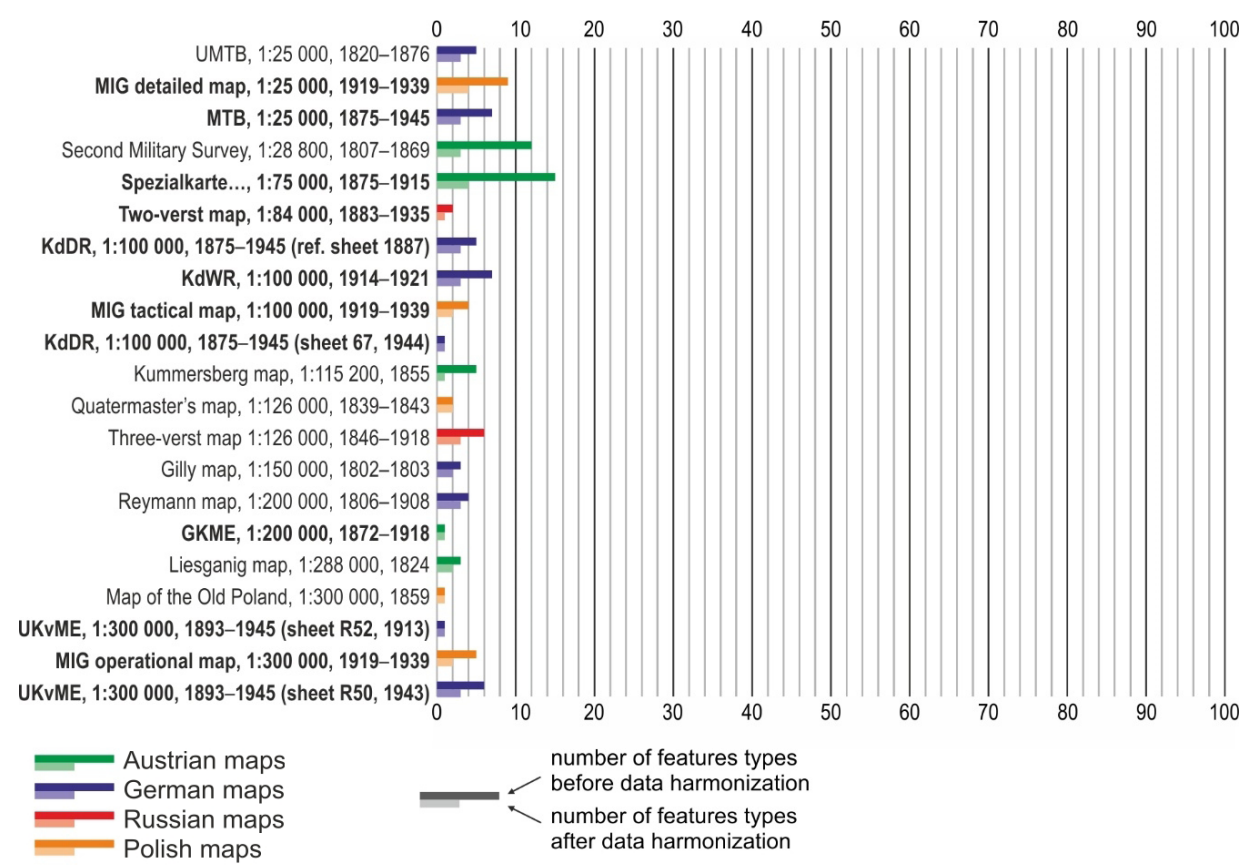

Map sheets in bold were published after 1870

Fig. 2. Number of feature types on different maps' key to symbols among "water network" feature class category (before and after harmonization) 
ditches on the basis of many maps. It is worth noting that the modern database does not include such an attribute.

The transport network is the most diverse thematic layer, and the average drop in the number of object types after conceptual harmonization of data is about $66.7 \%$. This is mainly due to the methods of classifying roads on maps and applying different criteria even within one map. Most commonly, distinctions between various roads were made on the basis of their surface material ("chaussee", "gravel", and "fascine" roads, and even "roads made of boards" on the Austrian Second Military Survey map). Other criteria included: function ("utility", "post", "military", "rural", and "connecting" roads), importance ("main", "side", and "local" roads) and condition ("well-maintained" and "unmaintained" roads). This last criterion was often reflected in the graphic design of the symbols (M. Niedźwiecka 2016).

Due to the above-mentioned diversity of road classification criteria, their harmonisation did not consist in assigning types from old maps to the types form a modern classification, but in developing a separate metalegend (based on historical and contemporary road categories). Individual road types were assigned to the specially created 5 relatively general categories: "highway or expressway", "main road", "se- condary road", "local road", and "special road". The roads which on the old maps were indicated as "winter roads" were foremost assigned to the last of the above-mentioned categories (T. Panecki 2014).

Other elements of this layer are also very varied. The old maps distinguished between many types of crossings, differentiating between them on the basis of their function (meant to be used by people, horses or carts) and sources of power (ferries with peddles, steam ferries, motorised ferries). There were also numerous paths, also divided into various subgroups, such as paths for pedestrians and riders, as well as "partially disappearing paths" (Austrian Spezialkarte).

The number of object types related to the transport network was the greatest in the case of Spezialkarte, MGI maps, and KdWR, and smallest on the maps of Chrzanowski, Kummbersberg, and Liesganig, as well as on the Topographic Map of the Polish Kingdom (fig. 3). There is no direct link between the number of object types and the scale of the map, it can be nevertheless stated that cartographers tended to use more diverse classification criteria (especially in relation to roads) after 1870 .

Out of all the analysed thematic layers, the land cover was the most homogeneous conceptual category, and the objects belonging to

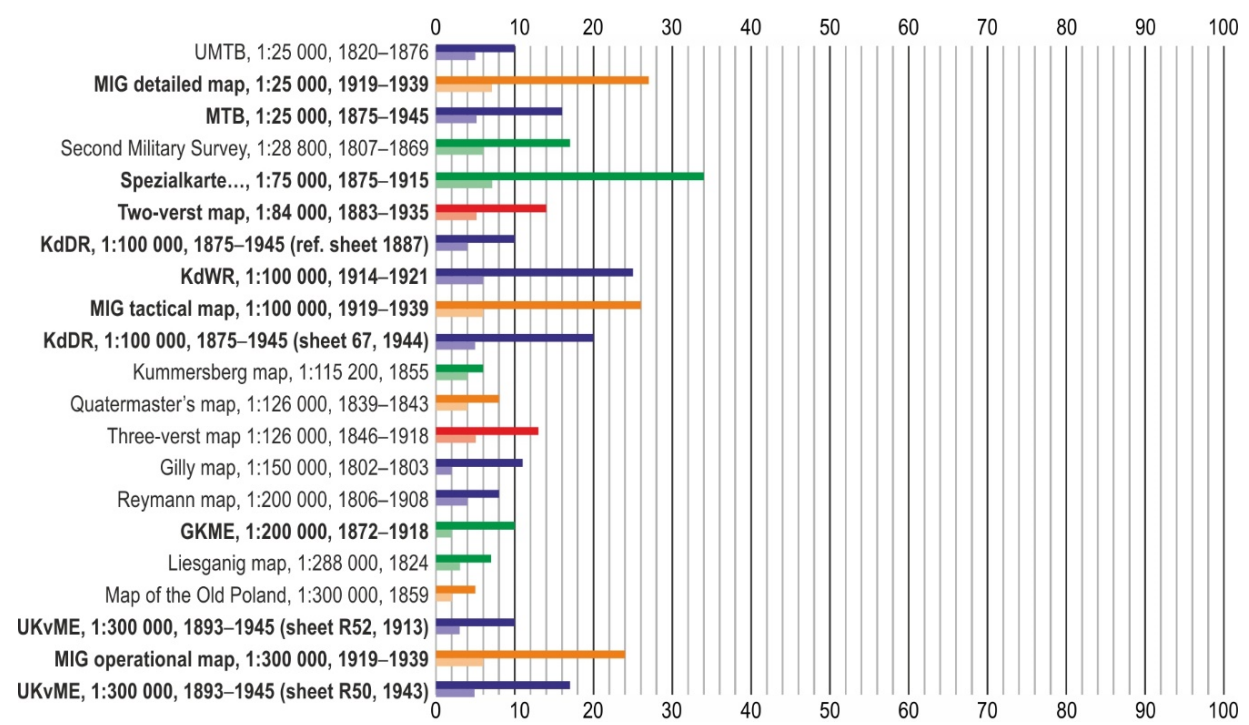

Fig. 3. Number of feature types on different maps' key to symbols among "communication network" feature class category (before and after harmonization) 
this layer were usually not distinguished by any additional characteristics. The decrease in the number of object types after harmonization was small and amounted on average to $26.5 \%$ The maps with most varied content are the Austrian 1:28,800 map (a drop of $54.8 \%$ ) and the German maps: UMTB and KdDR (in each case, a decrease by $50 \%$ ). 5 object types were classified on the Austrian map as the "surface water": among them such elements as "partially drained" and "boggy" ponds. On the other hand, the German maps distinguish between several different types of meadows: wet, dry and overgrown, which also influenced the conceptual diversity of these maps.

The decrease in the number of object types was below $50 \%$ in the case of other maps, and in the case of 5 of them, there was no decrease at all - only one object type from BDOT10k was identified for each type of land cover from the old maps (fig. 4). These were 3 Austrian maps (Kummersberg map, Liesganing map and GKME), German maps (Gilly map and UKvME in its older version) and the Karta Dawnej Polski (Map of Former Poland). Given the above-mentioned values, it is possible to come to an erroneous conclusion that the symbols indicating the land cover on the old maps had quiet high conceptual homogeneity in relation to contemporary criteria. However, despite si- milar names used to distinguish individual elements of land cover (in the past and today), we are not able to determine what the concept of forest or built-up area meant in the past and what were the detailed criteria for generalization - if they were even set at all, especially for older maps.

The most numerous group of objects are buildings, structures and installations (fig. 5). The highest number of object types can be found on the MGI 1:25,000 and 1:100,000 maps: (respectively, 97 and 96) and Austrian maps at the scale of $1: 75,000$ (87) and 1:28,800 (68). The dependence of the number of object types on the scale of the map is clearly visible: the lowest number of object types was distinguished on Liesganig map (4), the Map of Former Poland (6) and UKvME in its older version (8). Most important buildings (from topographic point of view), main churches, and on the German map also mills and windmills, are all depicted on these maps. The MGI operational map depicts as many as 50 objects, but most of them (31) are presented in the key to symbols in the form of explanatory abbreviations. It is difficult to say how many of them were really presented on the map.

Out of all the analysed maps, the Russia three-verst map and the Austrian Spezialkarte had the biggest drops in the number of object

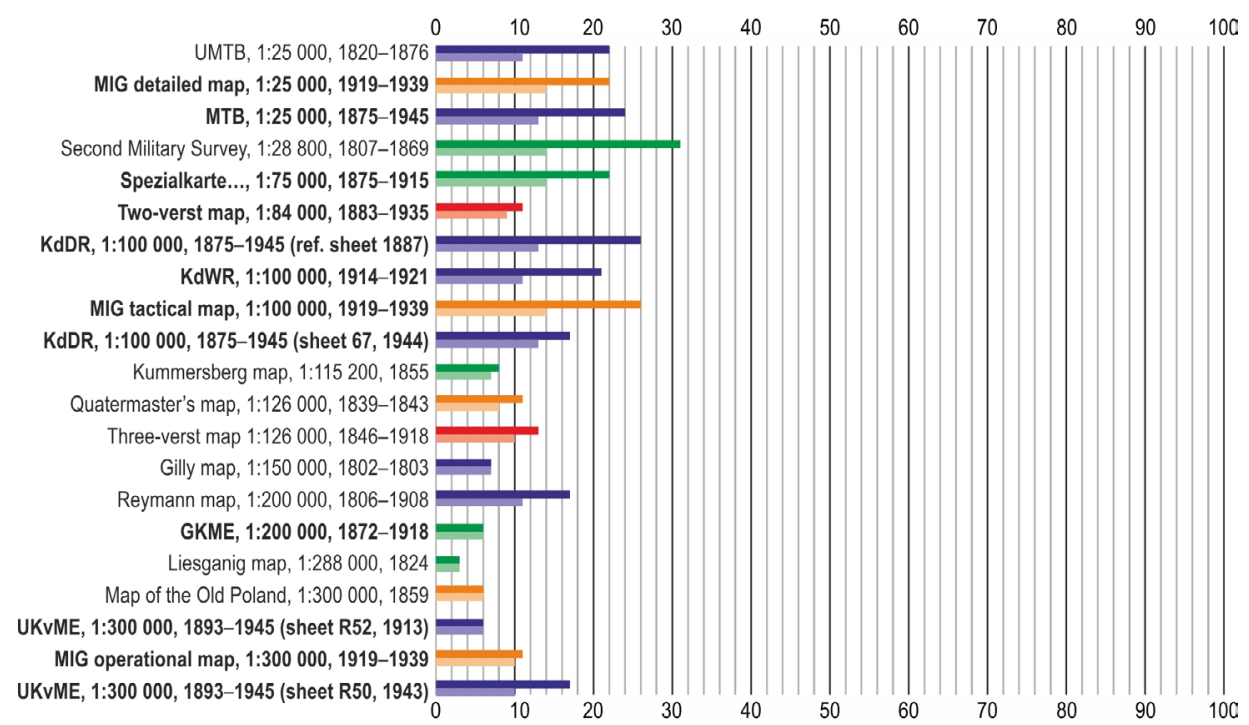

Fig. 4. Number of feature types on different maps' key to symbols among "land cover" feature class category (before and after harmonization) 


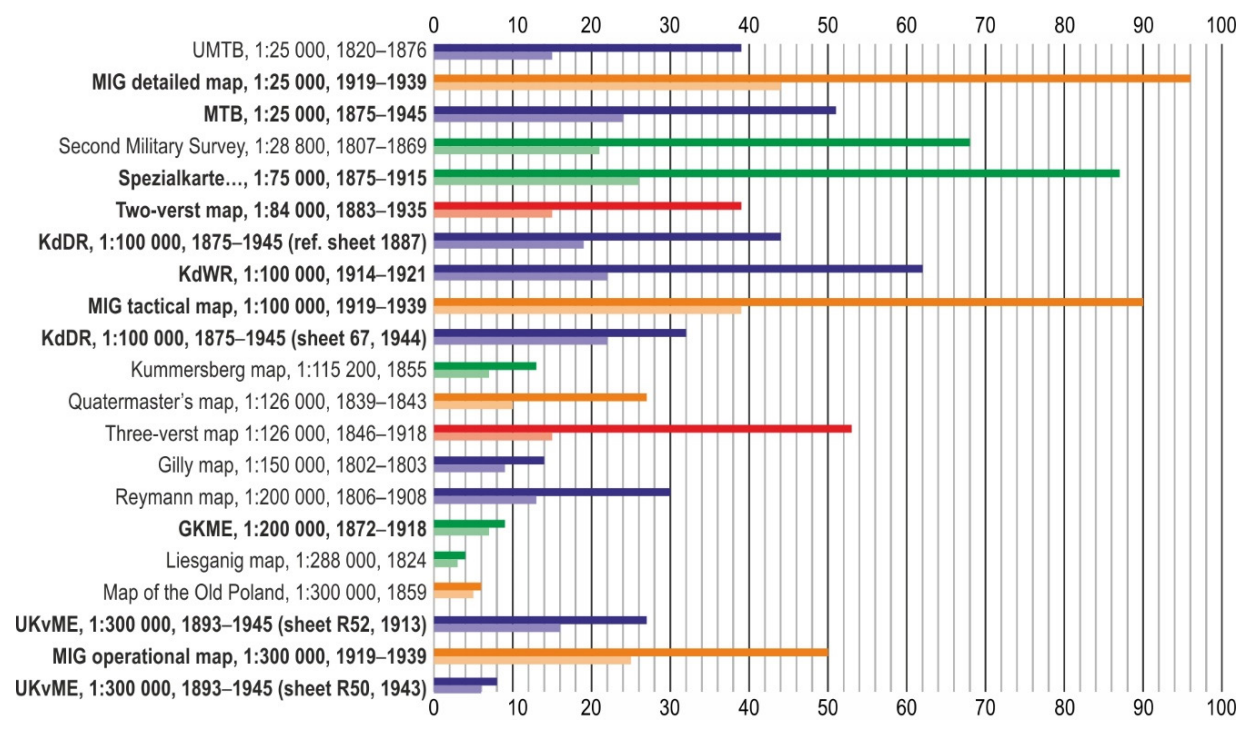

Fig. 5. Number of feature types on different maps' key to symbols among "buildings, structures and installations" feature class category (before and after harmonization)

types (respectively, $71.7 \%$ and $70.1 \%$ ), and therefore also the highest degree of variety. In the case of the Russian map, it is a result of the great variety of building types (most have separate symbols for wooden and brick buildings), whereas in the case of the Austrian map, bridges are the main source of the map's varied character, as the map distinguishes between different types of bridges on the basis of their construction materials (bridge deck and pillars) and the transportation type. There was even a separate symbol for "railway bridges which can be crossed by compact infantry units".

The second, most frequently represented layer is composed of land use complexes and includes objects representing areas which are homogeneous in terms of their functions (fig. 6). The greatest number of them was identified on the MGI maps at the scales of $1: 25,000$ and $1: 100,000$ (respectively 49 and 48 ) as well as on Reymann map (45) and the MGI 1:300,000 map (43). It is a consequence of a rich catalogue of explanatory abbreviations which constitute an element of the maps' keys to symbols. Most of them describe areas constituting land use complexes, foremost economic facilities. There is only one such object identified on the Map of Former Poland (a manor house) and the Austrian GKME (a railway station). The Ger- man 1:25,000 map from the first half of the 19th century is definitely most varied (a drop of $82.4 \%$ ). It is a consequence of the diversity of mines (11 types of extracted raw materials), as well as economic and industrial complexes (13 types).

In contrast to the previously discussed thematic layers, it is difficult to distinguish the types of localities on topographic maps in any unambiguously clear manner. Only a few out of all the analysed maps have a legend for markings distinguishing between various settlement units, and these often turn out to be insufficient, because the same typeface was used to indicate, for example, parts of villages, farmsteads and hamlets. It is possible to attempt to define the fullest possible catalogue of topographic objects which meet the definition of a locality on the basis of the on-line draught and the key to symbols ${ }^{1}$. Not only cities, towns and villages were considered to be localities in the designed model, but also a number of other topographic objects, which may be localities, for example

\footnotetext{
1 The following definition was adopted after DBTO10k: "Locality is a settlement unit or other built-up area having different name than other localities, and in case of the same name - belonging to a different type" (Rozporządzenie... 2011, p. 12).
} 


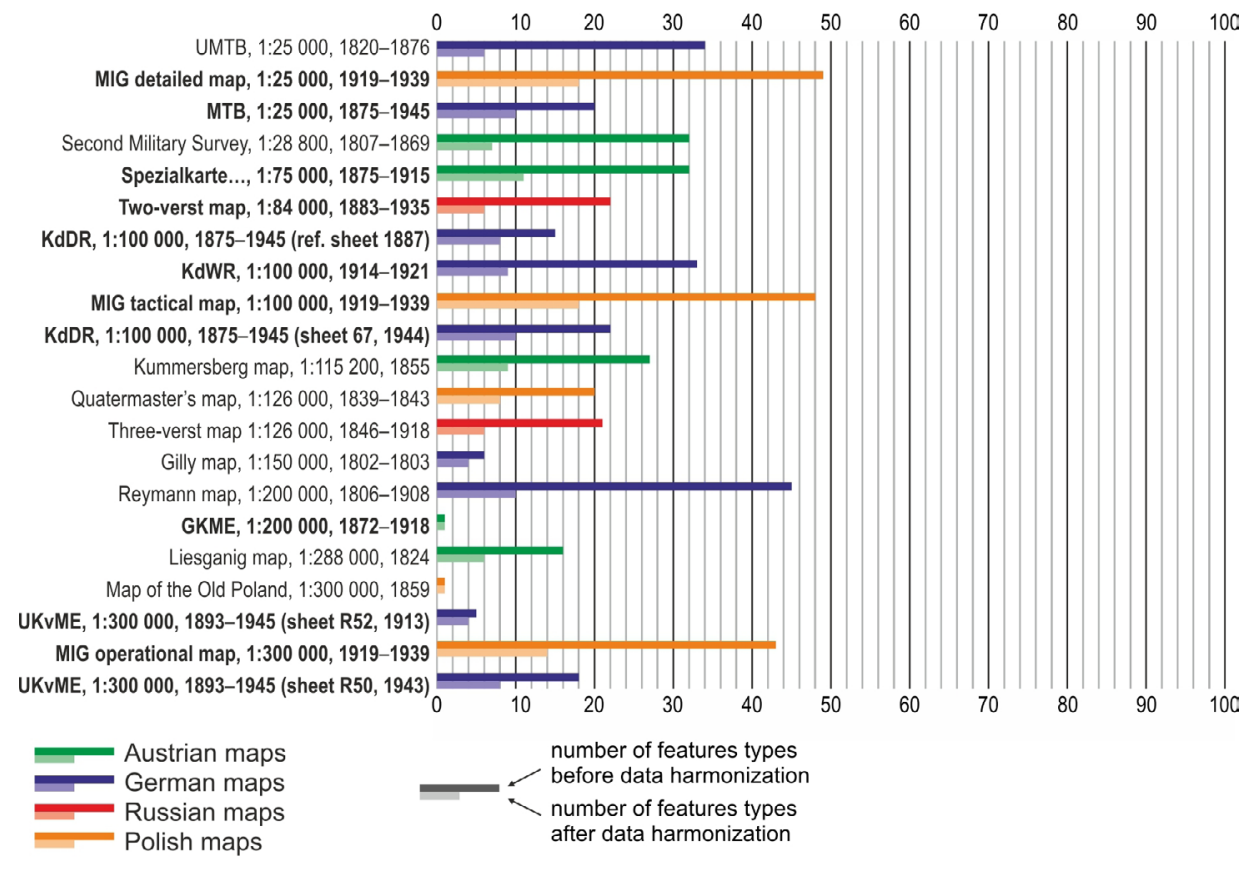

Map sheets in bold were published after 1870

Fig. 6. Number of feature types on different maps' key to symbols among "land use" feature class category (before and after harmonization)

farmsteads, manor houses, mills, taverns or forester's lodges, as long as they meet the definition of a locality, primarily in terms of their spatial and naming distinctiveness.

The conducted study shows that the biggest number of types of localities have been distinguished on the MGI 1:300,000 map and the KdWR 1:100,000 map (20), which is a result of the existence of an extensive system of qualitative symbols (MGI map) and writings (German map) (fig. 7). There was definitely a lower number of types of localities distinguished on the keys to symbols of the maps to which the administrative criterion was applied, dividing the localities into cities, towns and villages (e.g. Gilly map, Liesganig map and the Topographic Map of the Polish Kingdom).

The maps used different criteria for differentiating between the types of localities. For cities, the main criterion was their administrative function - e.g. district cities, poviat cities, as well their population sizes (it first appeared on the Austrian map - Spezialkarte). On the other hand, villages were usually divided into villages with churches and villages without churches, which is a consequence of the fact that the topographic maps were meant to be used for military purposes. Qualitative criteria (number of inhabitants, number of houses) were introduced later. Some maps divided villages on the basis of their morphogenetic qualities compact and dispersed development.

The last analysed layer consisted of "other objects" (fig. 8). It is a rather broad layer, conceptually speaking, which (just as the reference model, DBTO10k) contains objects that are not classified into other categories (including objects related to transportation, landmarks and natural objects). The largest number of objects of this type can be found on the Austrian Spezialkarte (46), and the smallest number is distinguished on Gilly map (2) and Chrzanowski map (1). This is the layer which contains the largest number of objects which were not included in the modern database, primarily natural objects and objects significant in their roles as landmarks. Such objects include for example signposts (Russian maps and older German maps) or border stones and milestones (older maps), as well as shipwrecks (MGI maps), light- 


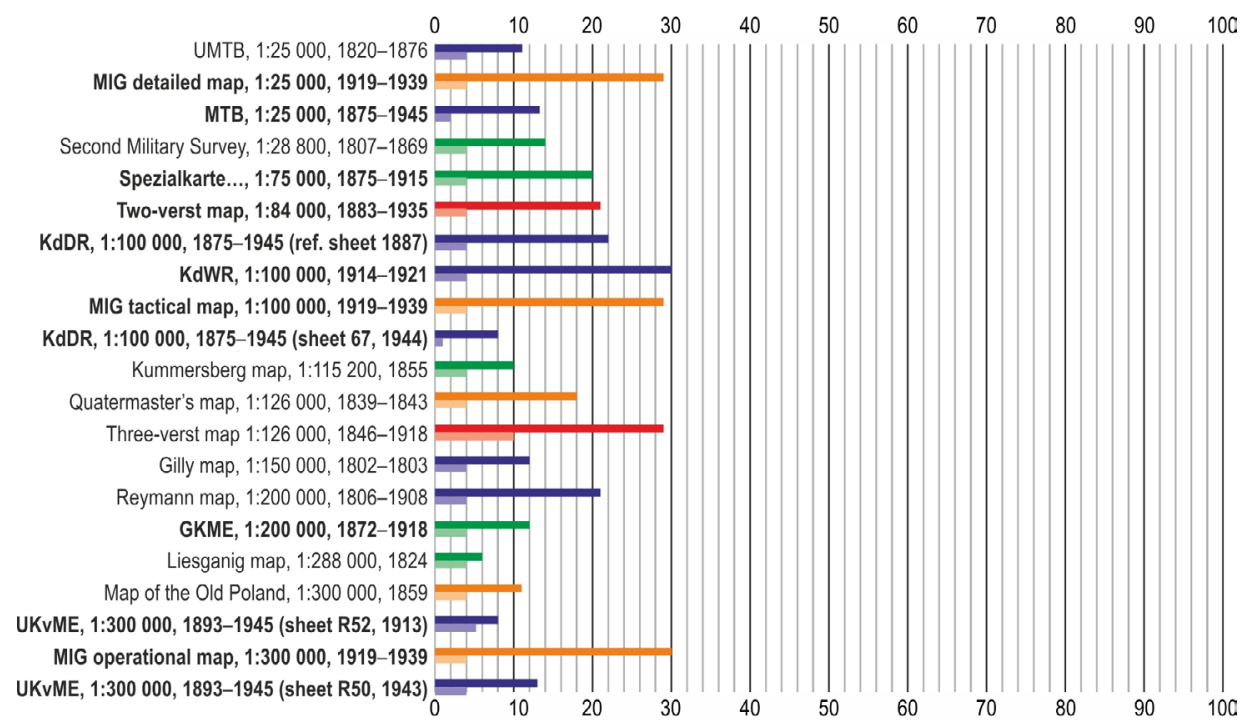

Fig. 7. Number of feature types on different maps' key to symbols among "administrative units" feature class category (before and after harmonization)

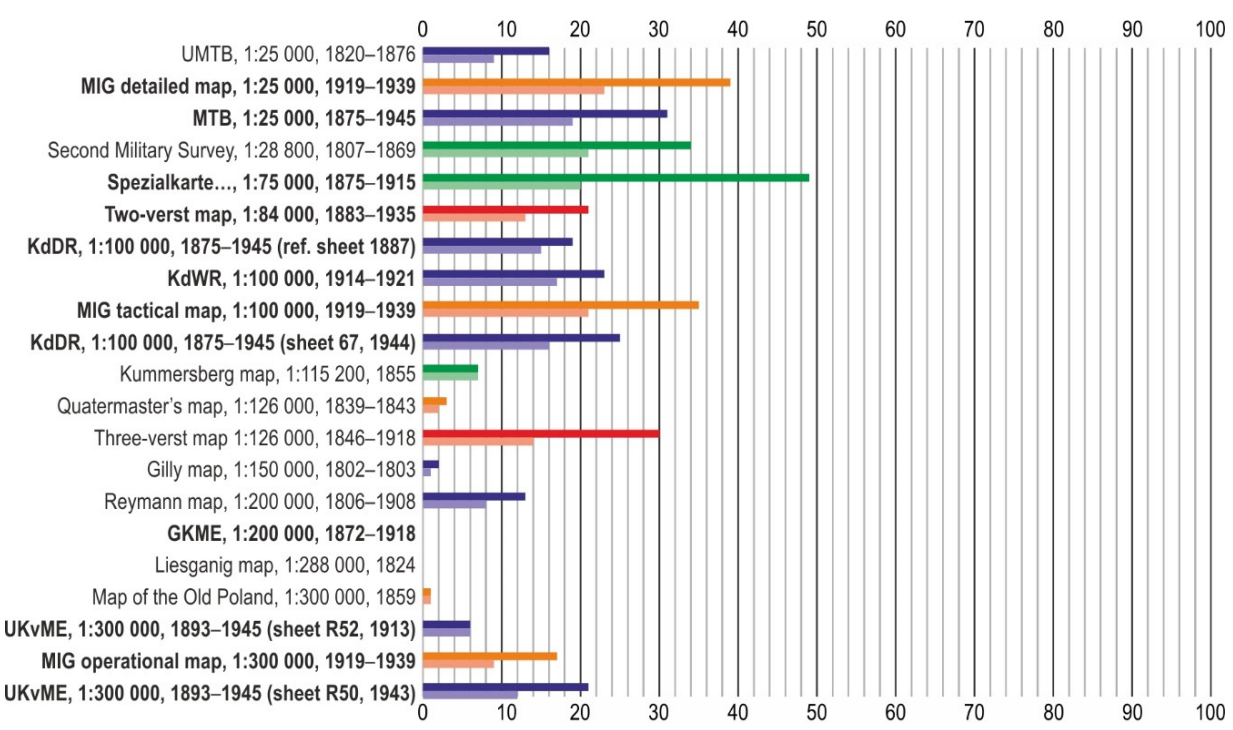

Fig. 8. Number of feature types on different maps' key to symbols among "other features" feature class category (before and after harmonization)

vessels ${ }^{2}$ or light buoys (newer German maps). Natural objects included such noteworthy elements as hedges, reefs and underwater rocks as well as rushes and reed beds. All these types

\footnotetext{
${ }^{2}$ A ship which performs the function of a lighthouse.
}

of objects were important in the past, as they could limit military activities, hence the need to depict them on maps. Interestingly, the biggest number of object types which are not included in DBTO10k was found on relatively modern, yet detailed maps: the German 1:25,000 map 
from the end of the 19th century and the MGI $1: 25,000$ map from the inter-war period.

\subsection{Scales, issue dates, creators}

The decrease in the number of object types after harmonization was also analysed in a more generalized way, i.e. divided in accordance with the succession of scales, the issue dates of the maps, as well as the maps' contractors (topographical services of individual countries) (table 5).

The smaller the scale, the more conceptually diverse the map, except for the object types related to the transportation network and localities, as roads and settlements constitute a back-
The variety in terms of the map producers, that is, the topographic services, is the biggest in the "buildings, structures and installations" category in which Russian maps (a decrease of about $66.6 \%$ ) differ significantly from other maps (a drop of about $46 \%$ ), as the key to symbols of the Russian three-verst map contains two variants (wooden and brick) for almost all types of buildings. The transportation network was by far the least varied category, and roads were presented with the same degree of detail on the old topographic maps of all countries.

The maps' elaboration dates have the greatest influence on the number of elements in the transportation network. The newer the map, the more detail the presentation of the road network, which is directly linked to the on-going

Tab. 5. Percentage decrease of feature types after harmonization for individual feature class categoies, broken down into different maps in terms of: scale, topographic service and date of issue

\begin{tabular}{|l|c|c|c|c|c|c|c|c|c|}
\hline \multirow{2}{*}{$\begin{array}{l}\text { Feature class } \\
\text { category }\end{array}$} & \multicolumn{4}{|c|}{ Scales } & \multicolumn{3}{c|}{ Topographic service } & \multicolumn{3}{c|}{$\begin{array}{c}\text { Date } \\
\text { of issue }\end{array}$} \\
\cline { 2 - 11 } & $\begin{array}{c}1: 25,000- \\
1: 28,800\end{array}$ & $\begin{array}{c}1: 75,000 \\
-1: 150,000\end{array}$ & $\begin{array}{c}1: 200,000- \\
1: 300,000\end{array}$ & Austrian & German & Russian & Polish & $\begin{array}{c}\text { before } \\
1870\end{array}$ & $\begin{array}{c}\text { after } \\
1870\end{array}$ \\
\hline water network & 58.0 & 42.3 & 24.0 & 52.3 & 33.6 & 50.0 & 32.0 & 35.8 & 41.3 \\
\hline $\begin{array}{l}\text { communication } \\
\text { network }\end{array}$ & 64.4 & 65.8 & 66.1 & 62.9 & 66.9 & 62.9 & 67.2 & 55.8 & 71.6 \\
\hline land cover & 49.1 & 28.0 & 12.2 & 18.5 & 34.9 & 20.6 & 23.4 & 22.6 & 29.5 \\
\hline $\begin{array}{l}\text { buildings, } \\
\text { structures and } \\
\text { installations }\end{array}$ & 59.5 & 55.8 & 32.0 & 44.6 & 47.2 & 66.6 & 48.1 & 49.6 & 49.9 \\
\hline land use & 68.5 & 60.1 & 40.6 & 54.5 & 54.4 & 72.0 & 51.6 & 58.3 & 53.7 \\
\hline $\begin{array}{l}\text { administrative } \\
\text { divisions }\end{array}$ & 62.0 & 89.5 & 85.0 & 83.6 & 74.3 & 89.0 & 91.4 & 83.1 & 81.8 \\
\hline other & 41.2 & 36.0 & 24.3 & 33.3 & 30.4 & 48.5 & 32.2 & 28.3 & 37.3 \\
\hline overall & 57.5 & 53.9 & 40.6 & 50.0 & 48.8 & 58.5 & 49.4 & 47.6 & 52.2 \\
\hline
\end{tabular}

bone of any topographic map and the degree of variety of this layer is similar regardless of the scale of the map in question. The biggest percentage decrease concerns land cover elements (a decrease of about $49.1 \%$ on the maps at scales of $1: 25,000-1: 28,800$ to a drop of about $12.2 \%$ on the maps at scales between $1: 200,000$ and 1:300,000). Generalisation consisted mainly of establishing conceptual links between various types of vegetation and grouping them into more general categories. technological progress. The differences concerning the land use complexes are relatively minor, and mostly concern commercial facilities. Their diversity is greater on maps created before 1870 , even though it is the second half of the 19th century that is associated with progressive industrialization.

The analysis of table 5 allows to answer the following question: which of these variables has the most impact on the amount of details and conceptual generalization (decrease in 
the number of object types) of the analysed layers. For each of the following layers, the most significant variable (or variables) is/are:

- water network - foremost the scale of the map and the topographic service,

- transportation network - elaboration date,

- land cover - scale, to a smaller extent, the topographic service,

- buildings, structures and equipment - scale,

- land use complex - scale and elaboration date,

- administrative division - it is difficult to indicate the variable which determines the level of detail of this category (it varies within individual maps),

- other objects - scale.

\section{Conclusions}

There is no doubt that the set of maps analysed in this article is very diverse, both in terms of quantity and quality. The old topographic maps differ in terms of the number and types of topographic objects they include, as well as their generalization and classification methods. Of course, the old maps follow some of the general trends known from contemporary general geography - for example the number of object types (and the detail of their representation) decreases with the reduction of the map's scale. However, there are also some

\section{Literature}

Czerny A. (ed.), 2015, Dawne mapy topograficzne w badaniach geograficzno-historycznych. Lublin. http://phvi.umcs.pl/at/attachments/20160708/103742 -czerny-dawne-mapy-07-07-low-res.pdf

Faluszczak F.P., 2011, Kartografia Galicji Wschodniej w latach 1772-1914. Rzeszów: Wydawnictwo Uniwersytetu Rzeszowskiego.

Gołębiowska I., Karsznia I., Mikiewicz D., Panecki T., 2012, Towards a historical GIS platform in Poland. In: Service-Oriented Mapping 2012. Ed. M. Jobst. Vienna, pp. 417-430.

Iwańczak W., 2008, Kilka uwag o dawnej mapie jako źródle historycznym. In: Dawna mapa źródłem wiedzy o świecie. Eds. S. Alexandrowicz, R. Skrycki. „Z Dziejów Kartografii” T. 14, Szczecin, pp. 51-60.

Konias A., 2010, Kartografia topograficzna państwa i zaboru pruskiego od II połowy XVIII wieku do połowy XX wieku. Słupsk: Wydawnictwo Naukowe Akademii Pomorskiej w Słupsku.

Konopska B., Ostrowski J., Pasławski J., Weszpiński P.E. (eds.), 2012, Dawne mapy jako źródła historyczne. tendencies which are characteristic specifically for maps from the 19th and the first half of the 20th century.

The general and topographical scale maps - Reymann map $(1: 200,000)$ and Polish and German 1:300,000 maps - are good examples of such characteristics. Their scope of content is less diverse than that of larger-scale maps, but they include some object characteristic for large-scale maps, such as various buildings (churches, mills, taverns), economic facilities (various types of production plants), and even landmarks used for orientation (roadside crosses). These objects cannot be found on contemporary maps of that scale, including DBGGO. The road network is subject to only a minor conceptual generalization as well. Paths are still included even in the keys to symbols of smaller-scale maps, although without the specific distinction between paths "for pedestrians" and "for riders".

Considering the results presented in the article in the context of the period they concern leads to a realisation that said results testify to the emerging concept of a topographical map as a carrier of general geographic information. It would be worthwhile to conduct similar analyses for twentieth-century and contemporary maps to assess whether they are more consistent and homogeneous in terms of their conceptual differentiation.

„Biblioteka Polskiego Przeglądu Kartograficznego” T. 3, Warszawa: Polskie Towarzystwo Geograficzne, Oddział Kartograficzny.

Kuna J., 2014, Zmiany znaków na XX-wiecznych mapach topograficznych $w$ skali 1:100 000. „Polski Przegląd Kartograficzny” T. 46, nr 1, pp. 47-61.

Lewakowski J., 1920, Klucz znaków przyjęty dla map austriackich, rosyjskich i pruskich. Warszawa, Kraków: Księgarnia J. Czarneckiego.

Libiński H., 1912, Jak czytać austriackie mapy wojskowe i orientować się za ich pomocą w terenie? Kraków: Księgarnia Gebethner i Spółka.

Niedźwiecka M., 2016, Analiza koncepcji graficznych systemów znaków na dawnych mapach Polski z XIX i I połowy XX wieku. Master thesis. University of Warsaw, Faculty of Geography and Regional Studies.

Olszewski R., Gotlib D. (eds.), 2013, Rola bazy danych obiektów topograficznych $w$ tworzeniu infrastruktury informacji przestrzennej w Polsce. Warszawa: Główny Urząd Geodezji i Kartografii. 
Panecki T., 2014, Creating a common symbol classification for a new historical geoportal of Poland. „Miscellanea Geographica” Vol. 18, no. 4, pp. 34-40.

Panecki T., 2015, The comparison of the scope of the content and classification methods on topographical maps of Polish territory annexed by Russia issued at the turn of 19th and 20th century. "Polish Cartographical Review" Vol. 47, no. 1, pp. 45-62 (http://doi.org/10.1515/pcr-2015-0004).

Pietkiewicz S., 1960, Analyse de l'exactitude de quel-

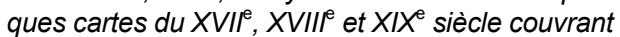
les territoires de l'ancienne Pologne. „Przegląd Geograficzny" T. 32, Suppl., pp. 21-27.

Plit J., 2014, Analizy geograficzne i historyczne dawnych map. In: Dawne mapy jako źródła w badaniach geograficznych i historycznych. Eds. B. Konopska, J. Ostrowski, „Z Dziejów Kartografii” T. 18, Warszawa, pp. 19-34.

Rozporządzenie Ministra Spraw Wewnętrznych i Administracji z dnia 17 listopada 2011 roku w sprawie bazy danych obiektów topograficznych oraz bazy danych obiektów ogólnogeograficznych, a także standardowych opracowań kartograficznych. Opis baz danych obiektów topograficznych i ogólnogeograficznych oraz standardy techniczne tworzenia map, tom 1, 2011. „Dziennik Ustaw Rzeczypospolitej Polskiej" No. 279, item 1642.

Stankiewicz M., 2000, Zdjęcia topograficzne na obszarze Królestwa Polskiego w XIX wieku In: Kartografia Królestwa Polskiego 1815-1915. Eds. J. Ostrowski, L. Szaniawska, „Z Dziejów Kartografii” T. 10, Warszawa, pp. 58-70.

Stankiewicz M., 2005, Współczesne rozumienie topografii. In: System informacji topograficznej kraju. Teoretyczne i metodyczne opracowanie koncepcyjne. Ed. A. Makowski. Warszawa: Oficyna Wydawnicza Politechniki Warszawskiej, pp. 49-57.

\section{Maps}

Administrativ-Karte von den Konigreich Galizien und Lodomerien [Kummersberg map], 1:115,200, sheet 06, 1855.
Generalkarte von Mitteleuropa [GKME], 1:200,000 (after H. Libiński 1912).

Karta Dawnej Polski, [Chrzanowski map], 1:300,000, sheet 05, 1859.

Karte des Deutchen Reiches [KDR], 1:100,000, specimen sheet, 1887 and sheet 67 (1944).

Karte des westlichen Russlands [KDWR], 1:100,000, specimen sheet, 1911.

Königreich Galizien und Lodomerien hereusgegeben on Jahre 1790 [Liesganig map], 1:288, 000, sheet Tab. XIX, 1824.

Mapa operacyjna WIG, 1:300 000, Znaki i objaśnienia do map 1:25 000, 1:100 000, 1:300 000. Warszawa: Wojskowy Instytut Geograficzny, 1937.

Mapa szczegółowa WIG, 1:25 000, Znaki iobjaśnienia do map 1:25 000, 1:100 000, 1:300 000. Warszawa: Wojskowy Instytut Geograficzny, 1937.

Mapa taktyczna WIG, 1:100 000, Znaki i objaśnienia do map 1:25 000, 1:100 000, 1:300 000. Warszawa: Wojskowy Instytut Geograficzny, 1937.

Messtischblätter [MTB], 1:25,000, 1940, sheet 3661. Reymann Spezialkarte [Reymann map], 1:200,000, specimen sheet, 1838.

Second Military Survey, 1:28,800, specimen sheet, 1834.

Special Karte von Südpreussen, aus der Königlichen Grossen Topographischen Vermessungs Karte unter Mitwürkung des Directors Langner reducirt und herausgegeben von Geheimen Bau-Rath Gilly [Gilly map], 1:150,000, sheet C1, 1803.

Spezialkarte der Osterreichisch-Ungarischen Monarchie [Spezialkarte...], 1:75,000, specimen sheet 1904.

Topograficzna Karta Królestwa Polskiego [Quatermaster's map], 1:126,000, sheet Kol. II, Sek. VIII, 1839.

Übersichtskarte von Mitteleuropa [UKvME], 1:300,000, sheet R52 (1913) and sheet R50 (1943).

Urmesstischblätter [UMTB], 1:25,000, specimen sheet, 1818.

Военно-топографрическая карта европейской Poccuu [Three-verst map], 1:126,000 (after J. Lewakowski 1920).

Новая Топографическая Карта Западной России [Two-verst map], 1:84,000 (after J. Lewakowski 1920). 